\title{
The Influence of Turkish Language on Bosnian Slang Culture
}

\author{
Lokman GÖZCÜ
}

\begin{abstract}
Societies live with their cultural values. Slang is an important part of culture. Slang excluded groups of society, is seen as the language of the rootless. Slang sometimes be equivalent to curse. However, slang is not swearing, it is just their society is an indicator of intelligence and sense of humor. Bosnian people are intelligent and capable people. They put these features are extracted from the slang expression ironic and humorous narrative. Bosnian people are one of the major points of cultural contact. Nevertheless, they have not lost their originality in the nations of the world. Bosnian authorities have remained at Ottoman about five hundred years. During this period Bosnian people are influenced by Ottoman language, literature, tradition, custom and extremely their belief. In some parts of recent history, they are named as Turkish people among southern Slavic societies. This approach is an important sign of how much they influenced by Turkish people. Today, there are many Turkish words which are used in Bosnian slang culture: "bilir bilmez", "maymune" etc. However, young Bosnian generation does not know that they are Turkish words. In this study, it will be find out influence of Turkish language to Bosnian slang culture by research and investigation, screening and router approaches.
\end{abstract}

Keywords: Bosnian culture, Turkish culture, Cultural interaction, Slang, Historical semantics. 